\title{
QUALITY OF VIRUS-FREE GARLIC GROWN UNDER HIGH ALTITUDE CONDITIONS IN THE SEMIARID REGION OF THE NORTHEAST OF BRAZIL ${ }^{1}$
}

\author{
ANTONIA TAMIRES MONTEIRO BESSA ${ }^{2 *}$, MARIA ZULEIDE DE NEGREIROS ${ }^{2}$, WELDER DE ARAÚJO RANGEL \\ LOPES $^{2}$, LAÍZA GOMES DE PAIVA ${ }^{2}$, OTACIANA MARIA DOS PRAZERES DA SILVA ${ }^{2}$
}

\begin{abstract}
Garlic is a vegetable rich in starch and in aromatic substances; it has high value as a spice and is consumed as a fresh vegetable or in processed products. The garlic market demand has been growing in the last years, and virus-free garlic seed is a technology that can result in better quality products. The objective of this work was to evaluate the quality of virus-free garlic cultivars (VFGC) grown under high altitude conditions in the Semiarid region of the Northeast of Brazil. Three experiments were conducted in 2018 in Portalegre, state of Rio Grande do Norte, Brazil: the first experiment with first-generation VFGC (G1), the second with second-generation VFGC (G2), and the third with infected cultivars (without clonal cleaning). The experiments were conducted in randomized block experimental design, with four replications. The treatments consisted of five garlic cultivars (Amarante, Branco-Mossoró, Cateto-Roxo, Gravatá, and Hozan). The use of virusfree garlic seeds results in bulbs with larger diameter and higher soluble solid and total solid contents, pungency, and industrial yield, showing that the seed health is important for the quality of garlics for fresh consumption and industrial processing. The cultivars Amarante, Cateto-Roxo, and Hozan had the highest total solid contents; and the cultivar Hozan had the largest bulb diameter and the highest soluble solid contents, pungency, and industrial index. The cultivar Hozan is the most indicated for dehydration due to its higher industrial index. Bulb diameter, pungency, and industrial index presented positive correlations with soluble solids, pungency, and industrial index.
\end{abstract}

Keywords: Allium sativum L. Soluble solids. Pungency. Industrial index. Phenotypic correlation.

\section{QUALIDADE DE ALHO LIVRE DE VÍRUS SOB CONDIÇÕES DE ELEVADA ALTITUDE NO SEMIÁRIDO NORDESTINO}

\begin{abstract}
RESUMO - O alho é uma hortaliça rica em amido e substâncias aromáticas de alto valor condimentar, podendo ser consumida tanto na forma in natura quanto industrializada. A exigência do mercado consumidor vem crescendo nos últimos anos, sendo o alho-semente livre de vírus uma das tecnologias capazes de proporcionar um produto final de melhor qualidade comercial. Com o objetivo de avaliar a qualidade de alho livre de vírus sob condições de elevada altitude no semiárido nordestino, três experimentos foram desenvolvidos em 2018 em Portalegre-RN. No primeiro experimento, utilizaram-se cultivares de alho livre de vírus (LV) de primeira geração (G1); no segundo, os cultivares LV de segunda geração (G2) e no terceiro, os cultivares que não passaram pela limpeza clonal (infectados). O delineamento experimental empregado, nos três experimentos, foi em blocos casualizados com quatro repetições. Os tratamentos foram constituídos pelos cultivares Amarante, Branco Mossoró, Cateto Roxo, Gravatá e Hozan. O alho-semente LV proporcionou maior diâmetro do bulbo, sólidos solúveis, sólidos totais, pungência e rendimento industrial, demonstrando que a sanidade do material propagativo é relevante na qualidade do alho para o consumo industrial. Para sólidos totais sobressaíram-se os cultivares Amarante, Cateto Roxo e Hozan, sendo esse último se destacado em diâmetro de bulbo, sólidos solúveis, pungência e índice industrial. Houve correlações positivas entre diâmetro de bulbos, pungência e índice industrial, e sólidos solúveis, pungência e índice industrial.
\end{abstract}

Palavras-chave: Allium sativum L. Sólidos solúveis. Pungência. Índice industrial. Correlação fenotípica.

\footnotetext{
${ }^{*}$ Corresponding author

${ }^{1}$ Received for publication in $05 / 08 / 2020$; accepted in $08 / 17 / 2020$.

Paper extracted from the doctoral thesis of the first author

${ }^{2}$ Department of Agronomic and Forestry Sciences, Universidade Federal Rural do Semi-Árido, Mossoró, RN, Brazil; tami.bessa@hotmail.com - ORCID: 0000-0002-8068-9068, zuleide@ufersa.edu.br - ORCID: 0000-0002-0665-326X, welder.lopes@hotmail.com - ORCID: 0000-0002-9380-6710, laizagomes@outlook.com - ORCID: 0000-0002-6645-369X, otaciana_silva@yahoo.com.br-ORCID: 0000-0002-0634-5419.
} 


\section{INTRODUCTION}

Garlic is a vegetable that stands out as one of the main spices used for cooking in the world; it has good flavor and mainly aroma characteristics. Organosulfur compounds are responsible for pungency, flavor, and aroma characteristics of this vegetable (BESSA et al., 2017).

Most garlic in Brazil is marketed fresh, but the searching for ready products in the last years has increased the marketing of garlic in paste, cream, and in dehydrated, dried powdered, preserved, and encapsulated oil forms (LUCENA et al., 2016).

Considering this increasing demand of the consumer market, the use of adequate cultural practices for garlic crops is essential, as well the use of technologies such as the virus-free garlic seeds, which results in high-vigor plants, high bulb yields, and high-quality bulbs regarding health and physiology, and makes the product to reach the market with good quality either for fresh consumption or industrial processing (RESENDE et al., 2013).

Soluble solid, total solid, and total soluble sugar contents, pungency, titratable acidity, and industrial index are among the physical-chemical characteristics used to evaluate the garlic quality (LOPES et al., 2016). The pungency and total solid contents are used to evaluate these characteristics and indicate whether a product is more appropriate for fresh consumption or industrial processing (CHITARRA; CHITARRA, 2005).

The garlic chemical composition and the its sensorial characteristics flavor and odor depend more on the genetic factor (cultivar) than on the crop conditions; however, they are also dependent on edaphoclimatic conditions of the environment in which the garlic plants will be grown and developed (LIMA et al., 2019).

Some studies evaluated the production and quality of garlic of the groups semi-nobre (SOARES, 2013; BESSA et al., 2017; LUCENA et al., 2016) and nobre (LOPES et al., 2016; HENRIQUES et al., 2019; SILVA, 2019) grown in the state of Rio Grande do Norte, Brazil; however, only one reported the quality of the garlic from virus-free seeds (cultivar Roxo Pérola do Caçador) in this region, evaluating clove-seed size and spacing between plants (LIMA et al., 2019).

Thus, the objective of this work was to evaluate the quality of virus-free garlic cultivars grown under high altitude conditions in the Semiarid region of the Northeast of Brazil.

\section{MATERIAL AND METHODS}

Three experiments were conducted simultaneously from May to October 2018, in the municipality of Portalegre, state of Rio Grande do Norte (RN), Brazil (6 $6^{\circ} 1^{\prime} 20^{\prime \prime} \mathrm{S}, 38^{\circ} 1^{\prime} 45^{\prime \prime} \mathrm{W}$, altitude of $520 \mathrm{~m}$ ). The climate of region is Aw, tropical rainy with a dry winter and a rainy summer, according to the Köppen classification, with mean annual rainfall depths from 800 to 1,200 mm (SEPLAN, 2019).

The soil of the experimental area is classified as a eutrophic Lithic Udorthent, which presented a loamy A horizon, medium texture (SANTOS et al, 2018), and the following chemical characteristics: $\mathrm{pH}_{\mathrm{H} 2 \mathrm{O}}$ of $6.2,53.4 \mathrm{mg} \mathrm{dm}^{-3}$ of $\mathrm{P} ; 241.9 \mathrm{mg} \mathrm{dm}^{-3}$ of $\mathrm{K}, 190.9 \mathrm{mg} \mathrm{dm}^{-3}$ of $\mathrm{Na}, 3.7 \mathrm{cmolc} \mathrm{dm}^{-3}$ of $\mathrm{Ca}, 1.4$ cmolc $\mathrm{dm}^{-3}$ of $\mathrm{Mg}, 0.0 \mathrm{cmolc} \mathrm{dm}^{-3}$ of $\mathrm{Al}, 0.83 \mathrm{cmolc}$ $\mathrm{dm}^{-3}$ of $\mathrm{H}+\mathrm{Al}, 6.55 \mathrm{cmolc} \mathrm{dm}^{-3}$ of sum of bases, 6.55 cmolc $\mathrm{dm}^{-3}$ of effective cation exchange capacity

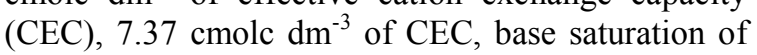
$89 \%$, aluminum saturation of $0.0 \%$, and exchangeable sodium of $11 \%$.

The first experiment was conducted with first generation of virus-free garlic cultivars (VFGC) (G1), the second with second-generation VFGC (G2), and the third with infected cultivars (without clonal cleaning). The experiments were conducted in a randomized block experimental design, with four replications.

The treatments consisted of five cultivars (Amarante, Branco-Mossoró, Cateto-Roxo, Gravatá, and Hozan) from the Brazilian Agricultural Research Corporation (Embrapa Vegetables, Brasília, DF, Brazil). The VFGC passed through a clonal cleaning process and were multiplied in controlled conditions.

The experimental plots consisted of beds of $0.20 \mathrm{~m}$ height, $1.0 \mathrm{~m}$ width, and $2.0 \mathrm{~m}$ length, with five planting rows. The seeds were planted to a depth of $0.05 \mathrm{~m}$, with spacing of $0.20 \mathrm{~m}$ between rows and $0.10 \mathrm{~m}$ between plants, to a population of 100 plants in a total area of $2.0 \mathrm{~m}^{2}$. The evaluated area of each plot consisted of the three central rows, discarding one plant from each end of the rows, resulting in a population of 54 plants evaluated in an area of 1.08 $\mathrm{m}^{2}$.

Soil preparation consisted of plowing and harrowing, followed by raising of beds using a motocultivator. Soil fertilizers were applied at planting, based on the soil chemical analysis and recommendations of Holanda et al. (2017) and Resende, Dusi and Melo (2004), using $30 \mathrm{~kg} \mathrm{ha}^{-1}$ of $\mathrm{N}$ (ammonium sulfate), $60 \mathrm{~kg} \mathrm{ha}^{-1}$ of $\mathrm{P}_{2} \mathrm{O}_{5}$ (simple superphosphate), $20 \mathrm{~kg} \mathrm{ha}^{-1}$ of $\mathrm{K}_{2} \mathrm{O}$ (potassium chloride), $14 \mathrm{~kg} \mathrm{ha}^{-1}$ of $\mathrm{Mg}$ (magnesium sulfate), $12 \mathrm{~kg} \mathrm{ha}^{-1}$ of $\mathrm{Zn}$ (zinc sulfate), $1.7 \mathrm{~kg} \mathrm{ha}^{-1}$ of B (boric acid), and $75 \mathrm{Mg} \mathrm{ha}^{-1}$ of a commercial fertilizer based on bovine and chicken manure (Pole Fértil ${ }^{\circledR}$ ) which presented $1 \% \mathrm{~N}, 15 \%$ organic $\mathrm{C}, 15 \%$ moisture, $\mathrm{pH}$ of 6.20 , and CEC of 74 mmolc $\mathrm{dm}^{-3}$.

The bulbs were threshed, and the cloves were classified by size and treated with $2.5 \%$ iprodione solution before planting to prevent possible attack of soil pathogens.

Topdressing consisted of two applications, at 
30 days after planting (DAP), using $30 \mathrm{~kg} \mathrm{ha}^{-1}$ of $\mathrm{N}$ (urea); and at $60 \mathrm{DAP}$, using $30 \mathrm{~kg} \mathrm{ha}^{-1}$ of $\mathrm{N}$ (urea) and $13 \mathrm{~kg} \mathrm{ha}^{-1}$ of $\mathrm{K}_{2} \mathrm{O}$ (potassium nitrate). Plant health protection was carried out using products based on Mancozeb (Manzate $\mathrm{WG}^{\mathbb{R}}$ ) and azoxystrobin (Amistar $\mathrm{WG}^{\circledR}$ ) for purple spot, and a product based on chlorfenapyr (Pirate ${ }^{\circledR}$ ) for pests, mainly thrips and mites. Weed control was carried out with manual weeding as needed.

A micro sprinkler irrigation system was used, with flow of $40 \mathrm{~L} \mathrm{~h}^{-1}$ and pressure of $200 \mathrm{KPa}$. The irrigation was suspended at five days before the harvest, when the first signs of plant maturation were observed leaf yellowing and drying of $2 / 3$ of the shoots.

The plants were harvested manually and subjected to a pre-cure process, remaining for three days exposed to the Sun, and then cured for 17 days in a dry, shaded, airy place.

The bulbs were cleaned and samples of 10 bulbs per plot were evaluated for transversal diameter $(\mathrm{mm})$ and mean bulb diameter $(\mathrm{mm})$. The bulbs were then threshed and the cloves of these samples were manually peeled and crushed in a food processor to obtain a garlic pasta, which was evaluated for the following characteristics:

soluble solids (SS): a juice obtained from the garlic pasta was homogenized, filtered in a $100 \%$ polyester fabric cloth, and read in a digital refractometer (Palette PR-100; Atago, Fukaya-shi, Japan). The results were expressed as percentages (AOAC, 2002).

total solids (TS): the cloves of ten bulbs were crushed and taken to a forced air circulation oven at $65{ }^{\circ} \mathrm{C}$ until constant weight. The total solids were calculated by the difference between 100 and the moisture content of the cloves. The results were expressed as grams of total solids per 100 grams of garlic (ZENEBON; PASCUET, 2005).

titratable acidity (TA): $1 \mathrm{~g}$ of garlic pasta from the crushed cloves was diluted in distilled water up to the volume of $50 \mathrm{~mL}$. Two drops of $1 \%$ alcoholic phenolphthalein were added and the titration was carried out with a $\mathrm{NaOH} 0.1 \mathrm{~N}$ solution until the turning point, characterized by a pink color. The results were expressed as $\mathrm{mEq} \mathrm{H}_{3} \mathrm{O}^{+} 100 \mathrm{~g}^{-1}$ (ZENEBON; PASCUET, 2005).

pungency: estimated by determining the pyruvic acid, using a 2,4-dinitrophenylhydrazine (DNPH) reagent, and the colorimeter method described by Schwimmer and Weston (1961): an extract was obtained by adding $0.2 \mathrm{~mL}$ of the juice obtained from the garlic pasta, $1.5 \mathrm{~mL}$ of $5 \%$ trichloroacetic acid, and $18.3 \mathrm{~mL}$ of distilled water to a Erlenmeyer, which was shaken. An aliquot of 1.0 $\mathrm{mL}$ of the extract was added to a test tube, together with $1.0 \mathrm{~mL}$ of DNPH solution and $1.0 \mathrm{~mL}$ of distilled water. The solution was shaken in a vortex; the test tubes were then taken to a water bath at $37^{\circ}$ $\mathrm{C}$ for 10 minutes. The solution was cooled in an ice bath and $5 \mathrm{~mL}$ of $\mathrm{NaOH} 0.6 \mathrm{~N}$ was added per test tube. They were then shaken in a vortex and left to rest for five minutes to develop a yellow color. The absorbances were read in a spectrophotometer at 420 $\mathrm{nm}$. Sodium pyruvate was used as standard. The pungency was calculated using the standard curve of sodium pyruvate with seven concentrations $(0.0,0.2$, $0.4,0.6,0.8,1.0$, and $\left.1.2 \mathrm{mmol} \mathrm{L}^{-1}\right)$. The results were expressed in $\mu$ Moles of pyruvic acid per $\mathrm{mL}$ of garlic juice.

industrial index (II), calculated by the formula: $\mathrm{II}=($ total solids $\times$ pyruvic acid $) \times 100$, according to Carvalho et al. (1991).

The data of each experiment were subjected to analyses of variance. After meeting the assumptions of homogeneity of variances and normality of errors between the experiments, the data were subjected to joint analyses of variance; the means referring to the health of garlic seed and cultivars were compared by the Scott-Knott test $(p \leq 0.05)$, using the Sisvar 5.4 program (FERREIRA, 2011). Pearson's correlation analysis was applied, using the t test at $1 \%$ and $5 \%$ probability.

\section{RESULTS AND DISCUSSION}

The interaction between garlic-seed health and cultivars was significant for all characteristics evaluated.

Plants from virus-free garlic seeds of first generation (G1) and second generation (G2) presented larger bulb diameter than the infected cultivars (Table 1).

The virus-free garlic cultivars (VFGC) presented larger bulb diameter than the infected cultivars; this is explained by the larger leaf area (plant height and number of leaves - data not presented) of VFGC in the field, which resulted in higher production of photoassimilates that promote the growth of bulbs. Leaves are essential for the photosynthetic process, which is required for synthesis of carbohydrates for the plant maintenance and growth and development of reserve organs (SINGH et al., 2013).

These results are consistent with those found in other studies (BIESDORF et al., 2015; RESENDE; MARODIN; SOUZA, 2018; LIMA et al., 2019), that showed larger bulb diameter for VFGC when compared to infected cultivars.

The G1 cultivars showed no significant differences in bulb diameter; however, considering the G2 cultivars, Branco-Mossoró, Cateto-Roxo, and Hozan presented higher means than Amarante and Gravatá. Among the infected cultivars, Hozan had larger bulb diameter $(46.01 \mathrm{~mm})$ than the other cultivars which had similar bulb diameters to each other (Table 1). Thus, Hozan had larger bulb diameter than the other cultivars, regardless of seed health. 
A. T. M. BESSA et al.

Table 1. Means of bulb diameter of garlic cultivars as a function of health of the garlic seeds.

\begin{tabular}{|c|c|c|c|c|}
\hline \multirow{3}{*}{ Cultivar } & \multicolumn{4}{|c|}{ Bulb diameter (mm) } \\
\hline & \multicolumn{4}{|c|}{ Seed health condition } \\
\hline & Virus-free (G1) & Virus-free (G2) & Infected & Means \\
\hline Amarante & $48.62 \mathrm{Aa}$ & $39.40 \mathrm{Bb}$ & $39.93 \mathrm{Bb}$ & $42.65 \mathrm{~b}$ \\
\hline Branco-Mossoró & $46.10 \mathrm{Aa}$ & $47.96 \mathrm{Aa}$ & $40.66 \mathrm{Bb}$ & $44.91 \mathrm{~b}$ \\
\hline Cateto-Roxo & $46.79 \mathrm{Aa}$ & $45.39 \mathrm{Aa}$ & $39.20 \mathrm{Bb}$ & $43.79 \mathrm{~b}$ \\
\hline Gravatá & $48.37 \mathrm{Aa}$ & $40.51 \mathrm{Bb}$ & $38.36 \mathrm{Bb}$ & $42.41 \mathrm{~b}$ \\
\hline Hozan & $49.53 \mathrm{Aa}$ & $46.78 \mathrm{Aa}$ & $46.01 \mathrm{Aa}$ & $47.44 \mathrm{a}$ \\
\hline Means & $47.89 \mathrm{~A}$ & $44.01 \mathrm{~B}$ & $40.83 \mathrm{C}$ & \\
\hline $\mathrm{CV}(\%)$ & \multicolumn{4}{|c|}{6.10} \\
\hline
\end{tabular}

Means followed by the same uppercase letter in the rows or lowercase in the columns, are not different by the Scott-Knott test at $5 \%$ probability.

Oliveira et al. (2010) evaluated infected garlic cultivars (without clonal cleaning) and found similar bulb diameters to those found in the present study for the cultivars Amarante (42.4 mm), Gravatá (44.0 $\mathrm{mm}$ ), Hozan (40.2 mm), and Cateto-Roxo (39.5 $\mathrm{mm}$ ). Lucena et al. (2016) found a mean bulb diameter of $27.94 \mathrm{~mm}$ for the cultivar Hozan in Governador Dix-sept Rosado, RN, Brazil, and 34.5 $\mathrm{mm}$ in Baraúna, $\mathrm{RN}$, Brazil; these means were below those found in the present work, and are explained by differences in edaphoclimatic conditions between Portalegre and those locations.

The mean contents of soluble solid (SS) (Table 2) and total solid (TS) (Table 3) were higher for G1 when compared to G2 and infected cultivars.

Table 2. Means of soluble solid contents in garlic cultivars as a function of health of the garlic seeds.

\begin{tabular}{ccccc}
\hline \multirow{2}{*}{ Cultivar } & \multicolumn{4}{c}{ Soluble solids (\%) } \\
\cline { 2 - 5 } & Virus-free (G1) & Virus-free $(\mathrm{G} 2)$ & Infected & Means \\
\cline { 2 - 5 } & $38.50 \mathrm{Aa}$ & $37.32 \mathrm{Bb}$ & $36.57 \mathrm{Bb}$ & $37.47 \mathrm{~b}$ \\
\hline Amarante & $34.63 \mathrm{Ab}$ & $33.25 \mathrm{Bc}$ & $34.70 \mathrm{Ac}$ & $34.19 \mathrm{~d}$ \\
Branco-Mossoró & $39.98 \mathrm{Aa}$ & $39.60 \mathrm{Aa}$ & $34.95 \mathrm{Bc}$ & $38.18 \mathrm{~b}$ \\
Cateto-Roxo & $38.85 \mathrm{Aa}$ & $33.93 \mathrm{Cc}$ & $35.50 \mathrm{Bc}$ & $36.09 \mathrm{c}$ \\
Gravatá & $39.53 \mathrm{Aa}$ & $39.20 \mathrm{Aa}$ & $38.48 \mathrm{Aa}$ & $39.07 \mathrm{a}$ \\
Hozan & $38.30 \mathrm{~A}$ & $36.66 \mathrm{~B}$ & $36.04 \mathrm{C}$ & \\
\hline Means & \multicolumn{4}{c}{2.60} \\
CV (\%) & \multicolumn{5}{c}{}
\end{tabular}

Means followed by the same uppercase letter in the rows or lowercase in the columns are not different by the Scott-Knott test at $5 \%$ probability.

Table 3. Means of total solid contents in garlic cultivars as a function of health of the garlic seeds.

\begin{tabular}{ccccc}
\hline \multirow{2}{*}{ Cultivar } & \multicolumn{4}{c}{ Total solids (\%) } \\
\cline { 2 - 5 } & Virus-free $(\mathrm{G} 1)$ & Veed health condition & Means \\
\cline { 2 - 5 } & $39.89 \mathrm{Aa}$ & $35.82 \mathrm{Bb}$ & $37.38 \mathrm{Ba}$ & $37.70 \mathrm{a}$ \\
Amarante & $36.85 \mathrm{Ab}$ & $35.66 \mathrm{Ab}$ & $35.92 \mathrm{Aa}$ & $36.14 \mathrm{~b}$ \\
Branco-Mossoró & $40.06 \mathrm{Aa}$ & $40.67 \mathrm{Aa}$ & $34.22 \mathrm{Ba}$ & $38.32 \mathrm{a}$ \\
Cateto-Roxo & $40.22 \mathrm{Aa}$ & $33.18 \mathrm{Bb}$ & $34.55 \mathrm{Ba}$ & $35.98 \mathrm{~b}$ \\
Gravatá & $40.13 \mathrm{Aa}$ & $40.14 \mathrm{Aa}$ & $37.64 \mathrm{Aa}$ & $39.30 \mathrm{a}$ \\
Hozan & $39.43 \mathrm{~A}$ & $37.09 \mathrm{~B}$ & $35.94 \mathrm{~B}$ \\
\hline Média geral & & 5.58 & \\
CV (\%) & \multicolumn{4}{c}{}
\end{tabular}

Means followed by the same uppercase letter in the rows or lowercase in the columns are not different by the Scott-Knott test at $5 \%$ probability. 
These results were probably due to decreases in net photosynthetic rates of infected cultivars, which was followed by accumulation of sugar starch in the leaves, which negatively affected the translocation of photoassimilates to the bulbs and resulted in lower SS and TS when compared to the virus-free garlic plants. In addition, Basso et al. (2010) reported that viruses are concentrated in the phloem and can disorganize tissues conductors, affecting their normal functioning, resulting in accumulation of starch and sugars in the leaves, which can cause significant decreases in photosynthetic rates and source-drain relations.

Considering the G1 cultivars, BrancoMossoró presented significant lower SS mean than the other cultivars, which had similar SS to each other. The G2 cultivars Cateto-Roxo and Hozan had higher SS percentages, followed by Amarante, Branco-Mossoró, and Gravatá, which had similar SS to each other. Among infected cultivars, Hozan had better performance, presenting higher SS (Table 2).

Differences in SS between cultivars may be caused by seed genetic characteristics and crop environment (LIMA et al., 2019). Mota et al. (2003) found $34 \%$ and $37.16 \%$ SS in the infected cultivars Cateto-Roxo and Amarante, respectively, which are similar results to those obtained in the present work.

The G1 cultivars presented higher total solid
(TS) contents, with mean of $40.07 \%$, except BrancoMossoró (36.85\%). Considering the G2 cultivars, Cateto-Roxo (40.67\%) and Hozan (40.14\%) had the higher TS means when compared to the other cultivars, which presented mean of $34.89 \%$. The infected cultivars presented no significant difference in TS, presenting a mean of $35.94 \%$ (Table 3 ).

TS above $30 \%$ are high and acceptable for processing, resulting in higher yields; thus, a high TS is a desirable characteristic for garlic industrial processing (CHAGAS; RESENDE; PEREIRA, 2003; BESSA et al., 2017). SS contents of VFGC were higher than those of infected cultivars. The garlic cultivars presented TS above $30 \%$, with good prospects for industrial processing, regardless of their seed health.

The cultivars Amarante, Gravatá, and Hozan presented no differences in titratable acidity (TA) in the three experiments (G1, G2, and infected cultivars); however, The cultivar Branco-Mossoró presented the highest TA among the G1 cultivars, whereas Cateto-Roxo presented the highest among the infected cultivars (Table 4).

Branco-Mossoró in G1 and G2 had higher TA mean (7.53 and $6.79 \mathrm{mEq} \mathrm{H} \mathrm{H}_{3}^{+} 100 \mathrm{~g}^{-1}$, respectively) than the other cultivars. The infected cultivars presented no significant differences in TA (Table 4).

Table 4. Means of titratable acidity of garlic cultivars as a function of health of the garlic seeds.

\begin{tabular}{|c|c|c|c|c|}
\hline \multirow{3}{*}{ Cultivar } & \multicolumn{4}{|c|}{ Titratable acidity $\left(\mathrm{mEq} \mathrm{H} \mathrm{O}^{+} 100 \mathrm{~g}^{-1}\right)$} \\
\hline & \multicolumn{4}{|c|}{ Seed health condition } \\
\hline & Virus-free (G1) & Virus-free (G2) & Infected & Means \\
\hline Amarante & $5.41 \mathrm{Ab}$ & $5.70 \mathrm{Ab}$ & $6.15 \mathrm{Aa}$ & $5.75 \mathrm{~b}$ \\
\hline Branco-Mossoró & $7.53 \mathrm{Aa}$ & $6.79 \mathrm{Ba}$ & $6.09 \mathrm{Ca}$ & $6.81 \mathrm{a}$ \\
\hline Cateto-Roxo & $4.98 \mathrm{Bb}$ & $4.87 \mathrm{Bc}$ & $5.62 \mathrm{Aa}$ & $5.15 \mathrm{c}$ \\
\hline Gravatá & $5.33 \mathrm{Ab}$ & $5.55 \mathrm{Ab}$ & $5.51 \mathrm{Aa}$ & $5.46 \mathrm{~b}$ \\
\hline Hozan & $5.33 \mathrm{Ab}$ & $5.44 \mathrm{Ab}$ & $5.69 \mathrm{Aa}$ & $5.49 \mathrm{~b}$ \\
\hline Means & $5.72 \mathrm{~A}$ & $5.67 \mathrm{~A}$ & $5.81 \mathrm{~A}$ & \\
\hline CV (\%) & & 7.93 & & \\
\hline
\end{tabular}

Means followed by the same uppercase letter in the rows or lowercase in the columns are not different by the Scott-Knott test at $5 \%$ probability.

Acidity in vegetable products is attributed to organic acids dissolved in the cell vacuoles in free and combined forms, such as salts, esters, and glycosides. TA is an important factor mainly for the industry, since the higher the acidity, the better the characteristics of garlic for use in industry (CHAGAS; RESENDE; PEREIRA, 2003; CHITARRA; CHITARRA, 2005). In this case, the cultivar Branco-Mossoró stands out with higher TA (6.81 $\left.\mathrm{mEq} \mathrm{H}_{3} \mathrm{O}^{+} 100 \mathrm{~g}^{-1}\right)$.

Lopes et al. (2016) and Lima et al. (2019) pointed out that variations in TA are related to environmental factors and cultivar genetic characteristics. Chagas, Resende and Pereira (2003) evaluated infected garlic cultivars (without clonal cleaning) in Lavras, MG, Brazil, and found TA of $0.71 \%$ for the cultivar Amarante. Lucena et al. (2016) evaluated the cultivar Hozan in two locations and found low variations in TA between the locations: Governador Dix-sept Rosado (6.54) and Baraúna $(6.79 \%)$. In the present study, the TA found for the cultivar Hozan and Amarante was 5.60\% and $6.15 \%$, respectively. Similar results found in different locations using the same cultivars confirm that TA is dependent on environmental factors. 
The pungency found for the VFGC in G2, except Cateto-Roxo, was higher than that found for the VFGC in G1 and infected cultivars (Table 5). Lima et al. (2019), evaluated garlic plants of the
Caçador cultivar and found higher pungency for virus-free seeds $\left(85.97 \mu\right.$ Mols of pyruvic acid $\left.\mathrm{mL}^{-1}\right)$ when compared to infected cultivars $(78.29 \mu$ Mols of pyruvic acid $\mathrm{mL}^{-1}$ ).

Table 5. Means of pungency of garlic cultivars as a function of health of the garlic seeds.

\begin{tabular}{|c|c|c|c|c|}
\hline \multirow{3}{*}{ Cultivar } & \multicolumn{4}{|c|}{ Pungency ( $\mu$ Mols of pyruvic acid $\mathrm{mL}^{-1}$ ) } \\
\hline & \multicolumn{4}{|c|}{ Seed health condition } \\
\hline & Virus-free (G1) & Virus-free (G2) & Infected & Means \\
\hline Amarante & $75.52 \mathrm{Aa}$ & $79.40 \mathrm{Ac}$ & $68.92 \mathrm{Bb}$ & $74.61 \mathrm{~b}$ \\
\hline Branco-Mossoró & $43.17 \mathrm{Cb}$ & $98.46 \mathrm{Aa}$ & $76.09 \mathrm{Ba}$ & $72.57 \mathrm{~b}$ \\
\hline Cateto-Roxo & $70.79 \mathrm{Aa}$ & $58.60 \mathrm{Bd}$ & $68.83 \mathrm{Ab}$ & $66.07 \mathrm{c}$ \\
\hline Gravatá & $73.16 \mathrm{Ba}$ & $82.68 \mathrm{Ac}$ & $80.89 \mathrm{Aa}$ & $78.91 \mathrm{a}$ \\
\hline Hozan & $76.54 \mathrm{Ba}$ & $87.32 \mathrm{Ab}$ & $70.40 \mathrm{Cb}$ & $78.09 \mathrm{a}$ \\
\hline Means & $67.84 \mathrm{~B}$ & $81.29 \mathrm{~A}$ & $58.95 \mathrm{~B}$ & \\
\hline $\mathrm{CV}(\%)$ & & 5.52 & & \\
\hline
\end{tabular}

Means followed by the same uppercase letter in the rows or lowercase in the columns are not different by the Scott-Knott test at $5 \%$ probability.

Among the G1 cultivars, Branco-Mossoró had the lowest mean pungency $(43.17 \mu$ Mols of pyruvic acid $\mathrm{mL}^{-1}$ ), and the other cultivars had mean of $74.0 \mu$ Mols of pyruvic acid $\mathrm{mL}^{-1}$, with no difference from each other. Among the G2 cultivars, BrancoMossoró presented the highest pungency (98.46 $\mu$ Mols of pyruvic acid $\mathrm{mL}^{-1}$ ) and Cateto-Roxo the lowest $\left(58.60 \mu\right.$ Mols of pyruvic acid $\left.\mathrm{mL}^{-1}\right)$; the other cultivars had mean of $83.13 \mu$ Mols of pyruvic acid $\mathrm{mL}^{-1}$. Branco-Mossoró and and Gravatá had higher pungency (76.09 and $80.89 \mu$ Mols of pyruvic acid $\mathrm{mL}^{-1}$, respectively) than the other infected cultivars, which presented mean of $69.38 \mu$ Mols of pyruvic acid $\mathrm{mL}^{-1}$ (Table 5).

Other works developed in the same region also reported pungency in the infected cultivars Amarante, Branco-Mossoró, Cateto-Roxo, and Gravatá. Lucena et al. (2016) found pungency of $80.69 \%$ and $75.85 \mu \mathrm{Mols}$ of pyruvic acid $\mathrm{mL}^{-1}$ in plants of the cultivar Hozan, respectively, grown in Baraúna (120 m altitude) and Governador Dix-sept Rosado (34 m altitude). Bessa et al. (2017) found pungency of $64.57 \mu$ Mols of pyruvic acid $\mathrm{mL}^{-1}$ in this cultivar, in Portalegre ( $520 \mathrm{~m}$ altitude). Soares (2013) found means of 94.84, 90.87, 94.46 and 92.58 $\mu$ Mols of pyruvic acid $\mathrm{mL}^{-1}$ in the cultivars Amarante, Cateto-Roxo, Branco-Mossoró and Gravatá, respectively. The results obtained in the present work and those of studies in other locations denote differences in pyruvic acid contents between cultivars in a same crop location, and for the same cultivar in different crop locations. Thus, regions with lower altitudes tend to present higher pungency. This was reported by Vargas et al. (2010) in Argentina; the pyruvic acid contents in the garlic cultivars Castaño-INTA, Sureño-INTA, LicanINTA, and Unión were higher in the Ushuaia (Tierra del Fuego, $16 \mathrm{~m}$ altitude) when compared to those found in the regions La Consulta (Mendoza, $950 \mathrm{~m}$ altitude) and Esquel (Chubut, $540 \mathrm{~m}$ altitude).

Pungency is an important characteristic for the choice of cultivars, since the higher the pungency, the stronger the flavor and aroma of the finished product, which is desired by consumers (LUCENA et al., 2016; LOPES et al., 2016) for fresh consumption and industrial processing.

The cultivar Amarante presented higher mean industrial index (II) in G1 and G2 than in the experiment with infected cultivars; Branco-Mossoró and Hozan presented higher II in G2 than in the G1 and infected experiments; the cultivar Gravatá in G1, G2, and infected experiments presented no difference in II; and the cultivar Cateto-Roxo presented higher II in G1 than in the G2 and infected experiments (Table 6). Thus, the infected cultivars, except Gravatá, had lower II, indicating that seed health is important to obtain a high-quality industrial product.

Lima et al. (2019) evaluated garlic plants of the cultivar Caçador in the same location evaluated in the present study and found II of 29.83 for VCGC and 27.57 for infected cultivars, confirming the results found in the present work.

Branco-Mossoro had the lowest II (15.91) in the G1 experiment, and the other cultivars had mean of 29.65 with no differences to each other. Contrastingly, Branco-Mossoró (35.10) and Hozan (35.04) had higher II than Amarante (28.45), Gravatá (27.43), and Cateto-Roxo (23.81) in the G2 experiment. The infected cultivars, except CatetoRoxo (23.59), had similar II, with mean of 26.88 (Table 6). The industrial index is obtained by the correlation between total solid (TS) contents and pungency ( $\mu$ Mols of pyruvic acid $\mathrm{mL}^{-1}$ ); therefore, cultivars that had higher TS and pungency had higher industrial index, with better quality for dehydration processing. 
A. T. M. BESSA et al.

Table 6. Means of industrial index of garlic cultivars as a function of health of the garlic seeds.

\begin{tabular}{|c|c|c|c|c|}
\hline \multirow{3}{*}{ Cultivar } & \multicolumn{4}{|c|}{ Industrial index } \\
\hline & \multicolumn{4}{|c|}{ Seed health condition } \\
\hline & Virus-free (G1) & Virus-free (G2) & Infected & Means \\
\hline Amarante & $30.12 \mathrm{Aa}$ & $28.45 \mathrm{Ab}$ & $25.77 \mathrm{Ba}$ & $28.11 \mathrm{~b}$ \\
\hline Branco-Mossoró & $15.91 \mathrm{Cb}$ & $35.10 \mathrm{Aa}$ & $27.32 \mathrm{Ba}$ & $26.11 \mathrm{c}$ \\
\hline Cateto-Roxo & $28.38 \mathrm{Aa}$ & $23.81 \mathrm{Bc}$ & $23.59 \mathrm{Bb}$ & $25.26 \mathrm{c}$ \\
\hline Gravatá & $29.42 \mathrm{Aa}$ & $27.43 \mathrm{Ab}$ & $27.95 \mathrm{Aa}$ & $28.27 \mathrm{~b}$ \\
\hline Hozan & $30.68 \mathrm{Ba}$ & $35.04 \mathrm{Aa}$ & $26.47 \mathrm{Ca}$ & $30.73 a$ \\
\hline Means & $26.90 \mathrm{~B}$ & $29.97 \mathrm{~A}$ & $26.22 \mathrm{~B}$ & \\
\hline $\mathrm{CV}(\%)$ & & 7.45 & & \\
\hline
\end{tabular}

Means followed by the same uppercase letter in the rows or lowercase in the columns are not different by the Scott-Knott test at $5 \%$ probability.

Several works have shown that II is a qualitative characteristic that varies depending on the environment in which the cultivars are grown. Lucena et al. (2016) found II of 26.42 and 27.22 for the cultivar Hozan, respectively, in Governador Dixsept Rosado and Baraúna. Soares (2013) found II of 27.00, 32.37, 30.22, and 29.04, respectively, for the cultivars Amarante, Branco-Mossoró, Cateto-Roxo, and Gravatá, in Governador Dix-sept Rosado. The II found in these studies are higher than those found in the present work and by Chagas, Resende and Pereira (2003), who found II of 19.42 for the cultivar
Amarante, in Lavras, MG, Brazil. These results obtained in different locations denote that higher pungency and, consequently, industrial index is obtained in regions with low altitudes (VARGAS et al., 2010).

The correlations between bulb diameter and pungency $(\mathrm{rF}=0.99)$ and between bulb diameter and II $(\mathrm{rF}=0.71)$ were significant and positive, denoting that bulb diameter is favored by pungency and II; the correlation between pungency and II was also significant $(\mathrm{rF}=0.76)$ (Table 7).

Table 7. Estimate of phenotypic coefficients of correlation between five quality characteristics of garlic cultivars as a function of the garlic seed health.

\begin{tabular}{cccccc}
\hline Characteristics & $\begin{array}{c}\text { Bulb diameter } \\
(\mathrm{mm})\end{array}$ & $\begin{array}{c}\text { Soluble solids } \\
(\%)\end{array}$ & $\begin{array}{c}\text { Total solids } \\
(\%)\end{array}$ & $\begin{array}{c}\text { Pungency } \\
\left(\mu \text { Mols of pyruvic acid } \mathrm{mL}^{-1}\right)\end{array}$ & Industrial Index \\
\hline Bulb diameter & - & $-0.08^{\mathrm{ns}}$ & $0.27^{\mathrm{ns}}$ & $0.99^{* *}$ & $0.71^{*}$ \\
Soluble solids & - & - & $0.89^{* *}$ & $0.01^{\mathrm{ns}}$ & $0.60^{*}$ \\
Total solids & - & - & - & $0.33^{\text {ns }}$ & $0.86^{* *}$ \\
Pungency & - & - & - & - & $0.76^{*}$ \\
Industrial index & - & - & - & - & - \\
\hline
\end{tabular}

$* *=$ significant at $1 \%$, and $*=$ significant at $5 \%$ by the $\mathrm{t}$ test.

The correlation between SS and TS $(\mathrm{rF}=0.89)$ and between $\mathrm{SS}$ and $\mathrm{II}(\mathrm{rF}=0.60)$ were significant, showing that SS contents are important for the quality of garlic for industrial processing, since the correlation between ST and II was highly significant $(\mathrm{rF}=0.86)$. Positive correlations denote simultaneous variance (covariance) of two variables in the same direction, i.e., proportional growth.

\section{CONCLUSIONS}

The use of virus-free garlic seeds results in bulbs with larger diameter and higher soluble solid and total solid contents, pungency, and industrial yield, showing that the seed health is important for the quality of garlics for fresh consumption and industrial processing.

The cultivars Amarante, Cateto-Roxo, and Hozan had the highest total solids contents, and the cultivar Hozan had the largest bulb diameter and highest soluble solid contents, pungency, and industrial index.

The cultivar Hozan is the most indicated for dehydration due to its higher industrial index. Bulb diameter, pungency, and industrial index presented positive correlations to soluble solids, pungency, and industrial index. 


\section{ACKNOWLEDGEMENTS}

The authors thank the Brazilian National Council for Scientific and Technological Development $(\mathrm{CNPq})$ for the financial support for this project and for granting a Research Scholarship (PQ2) to the second author; and the Brazilian Coordination for the Improvement of Higher Education Personnel (CAPES) for granting a doctoral scholarship to the first author.

\section{REFERENCES}

ASSOCIATION OF OFFICIAL ANALYTICAL CHEMISTRY - AOAC. Official methods of analysis of the Association of Official Analytical Chemistry.Washington: AOAC, 2002. 1115 p.

BASSO, M. F. et al. Fisiologia foliar e qualidade enológica da uva em videiras infectadas por vírus. Tropical Plant Pathology, 35: 351-359, 2010.

BESSA, A. T. M. et al. Caracterização físicoquímica de alho 'BRS Hozan' e 'Roxo Pérola de Caçador' em função do tempo de armazenamento. Revista Colombiana de Ciencias Hortícolas, 11: 368-377, 2017.

BIESDORF, E. M. et al. Desempenho agronômico de cultivares de alho vernalizado e não vernalizado na região Sudeste de Mato Grosso. Revista de Agricultura Neotropical, 2: 44-48, 2015.

CARVALHO, V. D. et al. Tempo de armazenamento na qualidade do alho cv. Amarante. Pesquisa Agropecuária Brasileira, 26: 1679-1684, 1991.

CHAGAS, S. J. R.; RESENDE, G. M.; PEREIRA, L. V. Características qualitativas de cultivares de Alho no sul de Minas Gerais. Ciência e Agrotecnologia, 27: 1584-1588, 2003.

Chitarra, M. I. F.; Chitarra, A. B. Póscolheita de frutas e hortaliças: fisiologia e manuseio. 2. ed. Lavras, MG: UFLA, 2005. 785 p.

FERREIRA, D. F. Sisvar: a computer statistical analysis system. Ciência e Agrotecnologia, 35: 1039-1042, 2011.

HENRIQUES, G. P. S. A. et al. Resposta do alho nobre vernalizado à adubação nitrogenada nas condições de cultivo do semiárido tropical. Científica, 47: 62-69, 2019.

HOLANDA, J. S. et al. Indicações para Adubação de Culturas em Solos do Rio Grande do Norte. 1. ed. Parnamirim, RN: EMPARN, 2017. 63 p.
(Documento 46).

LIMA, M. F. P. et al. Garlic quality as a function of seed clove health and size and spacing between plants. Revista Caatinga, 32: 966-975, 2019.

LOPES, W. A. R. et al. Caracterização físicoquímica de bulbos de alho submetido a períodos de vernalização e épocas de plantio. Horticultura Brasileira, 34: 231-238, 2016.

LUCENA, R. R. M. et al. Qualitative analysis of vernalizated semi-noble garlic cultivars in western Rio Grande do Norte State, Brazil. Revista Caatinga, 29: 764-773, 2016.

MOTA, J. H. et al. Características físico-químicas de cultivares de alho (AlliumsativumL.) do grupo seminobre, nas condições de Lavras, MG. In: CONGRESSO BRASILEIRO DE OLERICULTURA, 43, 2003, Recife. Anais... Brasília: ABH, 2003. 1 CD- ROM.

OLIVEIRA F. L. et al. Características agronômicas de cultivares de alho em Diamantina. Horticultura Brasileira, 28: 355-359, 2010.

RESENDE, F. V.; DUSI, A. N.; MELO, W. F. Recomendações básicas para a produção de alho em pequenas propriedades. 1. ed. Brasília, DF: Embrapa Hortaliças, 2004. 12 p. (Comunicado Técnico, 22).

RESENDE, J. T. V. et al. Caracterização morfológica, produtividade e rendimento comercial de cultivares de alho. Horticultura Brasileira, 31: 157-162, 2013.

RESENDE, F. V.; MARODIN, J. C.; SOUZA, R. J. Desempenho agronômico do alho infectado e livre de vírus em função do tamanho de bulbos bulbilhos utilizados para o plantio. 1. ed. Brasília, DF: Embrapa Hortaliças, 2018. 26 p. (Boletim de pesquisa e desenvolvimento, 170).

SANTOS, H. G. et al. Embrapa: Sistema brasileiro de classificação de solos. 5. ed. Brasília, DF: Embrapa, 2018. 356 p.

SCHWIMMER, S.; WESTON, W. J. Enzymatic development of pyruvic acid in onion as a measure of pungency. Journal of Agricultural and Food Chemistry, 4: 303-304, 1961.

SECRETARIA DE ESTADO DO PLANEJAMENTO E DAS FINANÇAS DO RN SEPLAN. Perfil do Rio Grande do Norte. Disponível em: <http://www.seplan.rn.gov.br/>. Acesso em: 20 jul. 2019. 
SINGH, S. R. et al. Character association and path analysis in garlic (Allium sativum $\mathrm{L}$ ) for yield and its attributes. SAARC Journal of Agriculture, 11: 45$52,2013$.

SILVA, O. M. P. Crescimento, acúmulo de macronutrientes e adubação fosfatada de alho nobre em região de altitude no Semiárido. 2019. 108f. Tese (Doutorado em Agronomia: Área de Concentração em Práticas Culturais) - Universidade Federal Rural do Semi-Árido, Mossoró, 2019.

SOARES, A. M. Avaliação de cultivares de alho no município de Governador Dix-sept RosadoRN. 2013. 104f. Dissertação (Mestrado em Agronomia: Área de Concentração em Práticas Culturais) - Universidade Federal Rural do SemiÁrido, Mossoró, 2013.

VARGAS, V. C. S. et al. Efecto de lainteraccióngenotipo-ambiente sobre la expresión delcontenido de allicina y ácido pirúvico en ajo (Allium sativum L.). Revista FCA UNCuyo, 42: 1522,2010

ZENEBON, O.; PASCUET, N. S. Métodos físicoquímicos para análise de alimentos. 4. ed. São Paulo, SP: IAL, 2005. 533 p. 